\title{
Motexafin Gadolinium
}

National Cancer Institute

\section{Source}

National Cancer Institute. Motexafin Gadolinium. NCI Thesaurus. Code C1881.

A synthetic metallotexaphyrin with radiosensitizing and chemosensitizing properties.

Motexafin gadolinium accumulates in tumor cells preferentially due to their increased rates of metabolism, generating reactive oxyg en species (ROS) intracellularly and lowering the tumor cell apoptotic threshold to ionizing radiation and chemotherapy. $(\mathrm{NCl04})$ 